\title{
Willingness to Pay for Tourist Tax in Destinations: Empirical Evidence from Istanbul
}

\author{
Gurel Cetin ${ }^{1, *}$, Zaid Alrawadieh ${ }^{2}$, Mithat Zeki Dincer ${ }^{3}$, Fusun Istanbullu Dincer ${ }^{1}$ and \\ Dimitri Ioannides ${ }^{4}$ \\ 1 Department of Tourism Management, Faculty of Economics, Istanbul University, Istanbul 34452, Turkey; \\ istanbul@istanbul.edu.tr \\ 2 Institute of Social Sciences, Istanbul University, Istanbul 34452, Turkey; zaid_rawadieh@yahoo.com \\ 3 Faculty of Economics \& Vocational School of Social Sciences, Istanbul University, Istanbul 34452, Turkey; \\ mzdincer@istanbul.edu.tr \\ 4 Department of Tourism and Human Geography, Mid-Sweden University, Östersund 831 25, Sweden; \\ dimitri.ioannides@miun.se \\ * Correspondence: gurelc@istanbul.edu.tr; Tel.: +90-212-4400000 (ext. 11681)
}

Academic Editor: Juan Ignacio Pulido Fernández

Received: 30 March 2017; Accepted: 13 June 2017; Published: 15 June 2017

\begin{abstract}
Revenue generated from tourism taxes constitutes an important financial resource for local governments and tourism authorities to both ensure tourism sustainability and enhance the quality of tourist experiences. In order for tourism policy makers to create an efficient and fair tax system in tourism destinations, it is crucial to understand travelers' perceptions concerning willingness to pay (WTP), tax rates, and their optimal allocation. The objectives of this paper, therefore, are to evaluate tourism taxes as a compensation tool to cover the costs of tourism and to measure tourists' WTP. The paper also suggests a fair allocation of tax revenues based on tourists' perceptions. A qualitative approach was used and data were collected through semi-structured in-depth interviews with international travelers to Istanbul, Turkey. The findings suggest that tourists are more likely to pay an additional amount of tax when this is earmarked for improvements in their experiences, but they are reluctant to take on liability concerning matters relating to destination sustainability. Based on the travelers' perceptions, the paper also identified areas that need investment to improve tourist experiences. An interesting highlight of this paper is that the majority of surveyed respondents reported that their travel decisions would not be negatively affected even if the total cost of their vacation increased by one third. The findings are expected to offer fresh and much-needed insights into tourist taxation for tourism policy makers and stakeholders.
\end{abstract}

Keywords: tourism taxation; tax system; tourism sustainability; tourism demand; externalities; price elasticity; destination management; Istanbul

JEL Classification: H21; Z32

\section{Introduction}

Tourism has been one of the fastest-growing industries globally and is expected to maintain 3.3\% annual growth for the next two decades. Tourism creates one in every 11 jobs, and accounts for $10 \%$ share of all global GDP (UNWTO 2015). The growth of international tourism flows to developing economies is expected to be even higher ( $4.4 \%$ annually). Tourism's phenomenal growth continues to attract the attention of national as well as local governments, since they see this sector as an avenue through which to meet their aims of enhancing public funds and creating stronger fiscal systems (Cárdenas-García et al. 2015). More physical investments (e.g., highways, airports, convention centers) 
and investment incentives (e.g., land allocation, tax returns) have appeared in government master plans to facilitate tourism development in recent years (Okumus et al. 2012).

Commonly, destination governments and lobbies of industry elites tend to overemphasize tourism's potential economic benefits while underplaying environmental and social impacts. Indeed, controls relating to environmental protection are imposed only when these are understood to lead to direct economic advantages for the destination. This situation means it is extremely difficult to implement solutions for sustainable development in many destinations, especially in developing countries (Fernández and Rivero 2009). Nevertheless, particularly in mature destinations there is a growing frustration with local inhabitants concerning tourism's negative effects on local resources. Uncoordinated tourism growth leads to a number of adverse impacts that reduce quality of life. These effects include: increased population; inflation; air and water pollution; congestion; crime; cultural conflicts and social change (Mihalič 2000). Despite increasing levels of discontent there is a lack of discussion on how the negative side effects of tourism can be prevented, compensated or distributed in a local context in a sustainable manner.

One way in which destinations seek to combat the social and environmental costs arising from tourism development is through the imposition of direct (e.g., city tax, lodging tax, car rental tax, entrance fees, visa fees) or indirect (e.g., sales tax, VAT) local corrective taxes. However, there are concerns about how these tourism related taxes are spent and what influence they may have on demand. The literature mentions different areas of investment and alternative uses of tax funds (Litvin et al. 2006). However, we do not yet have a comprehensive understanding of tourists' perspectives regarding the most efficient use of tax resources. Collecting a tax would not be fair if its payers are not consulted on how to spend the tax.

This paper looks into how tourists perceive these taxes, their price sensitivity, the ideal amount of tax, and earmarking of these taxes to specific areas of investment based on perceptions of tourists. The price elasticity of demand is an important metric to calculate an optimum level of tax, which would create maximum funds while placing minimum pressure on tourism demand. If policy makers have an understanding of tourists' willingness to pay and their investment choices, they might decide on optimal tax rates and most efficient and fair use of finances. The study explores the current situation in Istanbul as a case study for a possible consideration of lodging tax implementation in Turkey.

\section{Literature Review}

The tourism industry has witnessed dramatic growth in many parts of the world, but despite a growing understanding that it often causes adverse environmental and social impacts on destinations, all too often the emphasis continues to be on expanding visitor volume rather than adding value for its stakeholders. Even in Iceland, an advanced country that embraces many concepts of green living, there has been a dramatic growth of visitor arrivals in recent years. In 2016 there were a reported 1.7 million international tourists despite the fact that the country's total population is only 330,000 (BBC 2017). Thus, the industry's ability and motivation to attain sustainability principles are questionable. Tourism makes heavy use of free-shared resources such as nature, and sustainably managing these resources costs money. In fact, in the absence of financial support, it is hard to achieve sustainability (Hughes 1995). According to Burns and Holden (1995), both tourists and the industry that serves them should bear the costs for maintaining the environment. They argue that just like foreign companies are charged for extracting oil, foreign tourists should also be charged for the benefits they derive from the use of common goods and public services at a destination.

The socio-cultural, economic and environmental costs brought by the exponential growth of tourism have elevated the debate on sustainability, especially in urban destinations. Sustainability can be simply defined as an optimal use of exhaustible resources that ensures the well-being of both the current generation and the generations to come (Solow 1974,1991). Extensive research exists on urban tourism sustainability (e.g., Miller et al. 2015; Hinch 1996; Hunter 1997). From the perspective of the triple-bottom-line approach, sustainability is referred to with a focus on the environmental, social, 
and economic dimensions (Perez and Bosque 2014). Environmental sustainability refers to the optimal and adequate use of environmental resources that ensures both an enhancement of the tourist experience and the competitiveness of the destination (Hassan 2000). These resources are regarded as core resources that make a given destination attractive to visit (Dwyer and Kim 2003). Travelers' concern about environmental resources and their willingness to support environmental sustainability have received increasing attention from practitioners and scholars (e.g., Dodds et al. 2010). Environmental sustainability in destinations is widely discussed with regard to its relationship with responsible tourist behavior (Su and Swanson 2017). Economic sustainability, by contrast, refers to an environment where the economy is "dynamically efficient and the resulting stream of total welfare functions is non-declining over time" (Stavins et al. 2003, p. 341). The notion of economic sustainability has its roots in the extensive discussion on income in the pioneering work of Hicks, Value and Capital (first appeared in 1939). According to Hicks (1946), income is the maximum value one can consume during a specific period of time while expecting the same level of wellbeing at the end of the period. From the perspective of tourism destinations, however, economic sustainability lies mainly in maintaining an optimal development growth rate that takes into account the limits of a given destinations (Choia and Sirakaya 2006). Finally, the social dimension of sustainability refers to the understanding and respect of the local culture, traditions, and values in a given destination (Perez and Bosque 2014).

The resources that tourists use are mostly common resources, which are also consumed by the locals. The tragedy of the commons according to Hardin (1968) is that these resources will inevitably be destroyed because no one is assigned to monitor and control their usage (e.g., culture, scenery, air), despite the fact they are used by many in a manner that exceeds their limits to regenerate and be restored. If tourism is to merit its label of being the hospitality industry, it must look beyond its own customers and carefully consider the environmental, social, and cultural impacts it is creating on the host community at large. There is a saturation level for tourism in any given locality or region, and if that level is exceeded the costs of tourism begin to outweigh the benefits (Young 1973). Doxey (1975) explains, for example, how irritated the locals can become if their tolerance levels are exceeded. After a certain level of tourism activity, locals start to compete with tourists for resources such as space, water, parking, litter, sewage, transportation, visiting and shopping lines, or even for the favorite spot for viewing the scenery (Young 1973).

The inconvenience caused by an increased tourism volume can become more tolerable from the perspective of the residents in situations when compensation or some sort of benefit is offered to the locality (Murphy 1985). Internalizing the environmental and social costs of tourism and its production function is required and possible through public intervention (Green et al. 1990; Clarke and Ng 1993). In many destinations, tourists already pay some general indirect taxes such as sales tax/VAT, and the tourism industry also contributes to government fiscal budget though income tax. General sales taxes collected from tourism represent more than $10 \%$ of tax receipts for most developing countries. In the case of Turkey, for example, Cetin (2014) found that 35\% of tourist spending goes to the central government in the form of tax revenues. This figure is even more striking for smaller tourist economies such as Hawaii (Shareef and McAleer 2005).

Yet, some authors claim that in order to justify the distribution of costs associated with tourism activity, more specific — including regional — taxes are needed. A lodging tax (also referred to as city tax, occupancy tax, hotel tax, room tax, bed tax) is the most common specific tax used by governments for this purpose (Gago et al. 2006). There are also other methods that are employed to directly charge tourists such as visa fees, entrance supplements, car rental fees and so on. In an effort to shift some of the tax burden to non-residents, local governments have used lodging taxes; however, such a measure is strongly opposed by the hospitality industry and perceived as an unfair tool that harms companies' competitiveness (Aguiló et al. 2005).

Local governments, Convention and Visitors Bureaus (CVBs), and NGOs supporting lodging taxes claim that the lodging industry in the destination is better off because of the uses made by tax receipts (Litvin et al. 2006). They argue that the local tourism industry benefits from the extended services local 
authorities are able to provide such as transportation, landscaping, cultural events, increased capacity, security, safety, and convention centers. By contrast, tourism industry representatives claim that such a tax has negative impacts on tourism demand and competitiveness of the destination, which would reduce receipts and, consequently, the total VAT collected. Various studies have stressed the total cost of travel (e.g., Kozak and Rimmington 1999) as significant in determining destination competitiveness. Valle et al. (2012) also found that even when it is earmarked for environmental protection, tourists are not willing to pay an accommodation tax. However, the study was conducted in Algarve on sunlust tourists whose levels of awareness of the negative environmental impacts of tourism and their concern about environmental well-being were regarded as being low. The study also attributed sun-loving tourists' disapproval of an accommodation tax to their suspicion that these revenues would not actually be allocated for environmental purposes. Yet travelers with other motivations (e.g., cultural tourists) might have different perspectives as to their responsibility to local people and the environment.

There are at least three different groups of stakeholders (locals, tourists, and the tourism industry) in destinations with arguably varying interests and opinions regarding the impact of tourist taxes. However, even pro-tourist tax studies accept the fact that funds collected through tourism activity should be spent in areas related specifically to tourism. This is not the case in the majority of destinations, as studies have shown, where local governments regard taxes from tourism industry as free revenue, since tourists are unlikely to vote (Hiemstra and Ismail 1993). However, there is always the issue as to how much tax to charge, since if this tax is considered excessive, it might also adversely impact demand for lodgings, thus causing a hidden cost in the form of declining sales and overall tax revenue. By contrast, the perceived fairness with regard to tourism tax seems to be of a particular importance as travelers' behavior may be significantly influenced by their respective fairness perceptions (Chung et al. 2011). Fairness is a psychological perception of what is just or honest (Stapel 1972). In this sense, exploring travelers' perceptions on how to spend the tax would help in determining both fair tax rate and fair tax allocation.

There is also the problem of how to spend the finances created from tourist taxes. Although general sales taxes collected tend mostly to go to a central general fund, a major share of city taxes are expected to be spent on local tourism-related expenses (Litvin et al. 2006). This local fund (usually administered by a local agency that consists of industry members, NGOs, and local authorities) shall invest in promoting the destination, improving tourism infrastructure and supporting measures at promoting sustainable development while improving the quality of tourist experience. This earmarking of the tourist tax through a local committee might create the investments that would yield larger returns for the hospitality industry and local government in the long run, as well as create more democratic decision-making. Therefore, taxes collected from tourism-related activity at a destination should be spent carefully, in a just and effective manner, in order to ensure long-term growth in revenues. The underlying logic behind the cycle is that spending on projects that directly or indirectly can serve to improve the tourism product (e.g., infrastructure, preservation, promotion, tourist experience, local tourism events) will have a positive effect on demand, which will increase tax revenues even further, creating a self-reinforcing cycle.

Different studies have been conducted to measure the impacts of tourist taxes. Price elasticity of tourism demand is the key measure used by most of the researchers to quantify the possible impacts of tourist tax. Although some researchers found the impact of tourist taxes to be insignificant on demand (Bonham et al. 1992; Mak and Nishimura 1979), even insignificant changes bring an important burden for the hospitality industry considering the slim profit margins (Hiemstra and Ismail 1993). According to Wilson et al. (2001), inadequate funding is also one of the biggest obstacles to destination development and promotion. The quality of tourism services is a significant factor affecting the tourist experience and positive behavioral intentions. Therefore, the allocation of funds created by tourism-related taxes should be spent wisely. The tax can also be used to decrease the adverse effects of tourism on local quality of life. The aim of this paper, therefore, is to evaluate tourism related taxes 
as a compensation tool to cover the costs of tourism as well as to measure tourists' willingness to pay (WTP) and suggest a fair allocation of these funds based on tourist perceptions.

\section{The Case of Istanbul}

For Turkey, and specifically Istanbul, tourism constitutes a critical component in government finances and its importance is ever-increasing (Sariisik et al. 2011). Despite various crises, international arrivals in Turkey increased from 10 million to 31 million between 2000 and 2016. During the same period, international arrivals in Istanbul grew from 2 million to 8 million (TurkStat 2017). The increase in demand is also reflected by changing prices. This rapid development has caused some pressure on public services (e.g., transportation, sewage, security, health care) in the city. It should be considered that Istanbul is effectively a mega-city, being the fifteenth largest city in the world by population with more than 14 million inhabitants. Although tourists are temporary visitors, the pressure they create can still be viewed as significant regarding the seasonal and spatial concentration of tourist demand during different periods of the year on specific touristic areas in the city.

Istanbul has also been one of the pioneer destinations in the world, especially for cultural and heritage tourism (Alvarez and Yarcan 2010). The decision to undertake a study concerning visitors' perceptions towards tourism taxes in this city was inspired by the fact that previous research on this theme has focused heavily on sun-loving, mass tourism destinations (e.g., Valle et al. 2012), and neglected urban cultural destinations. Travelers visiting urban destinations are considered more respectful to local culture and nature (Cetin and Bilgihan 2016), as opposed to those who visit mass seaside resorts. Istanbul as a cultural destination is also one of the top 10 city destinations popular among international visitors worldwide (UNWTO 2015). In recent years, the city has witnessed significant growth both from a demand and supply perspective. There are currently around 185,000 beds and additional capacity amounting to 45,000 beds is planned to be ready in 2017 (Istanbul Culture and Tourism Directorate 2016).

Istanbul is a mature urban destination. Urban tourism is discussed as a form of tourism, which takes place specifically in cities and involves wide consumption of a variety of tourism products such as culture, shopping, entertainment, and business (Forgas-Coll et al. 2012). Unlike rural or non-urban destinations, tourism products in urban destinations are rapidly consumed as tourists are more likely to spend less time in these destinations (Ashworth and Page 2011). Conversely, tourism in urban destinations in particular represents several challenges, such as those arising from the heavy spatial concentration of tourists in historical and cultural sites, and the excessive use of public facilities such as mass transportation (Timur and Getz 2009). Therefore, achieving sustainability can often be far more challenging in urban destinations than in other types of destinations (Miller et al. 2010). Given the adverse impacts of tourism on the quality of life of both tourists and locals, ensuring sustainable urban tourism has become a common responsibility in which travelers visiting destinations are supposed to take part (Dodds et al. 2010). In this sense, revenues generated from tourist taxes are significant for the economic and environmental sustainability of urban destinations (Palmer and Riera 2003).

Despite challenges over the last two years due to various terror attacks, internal and external political issues and crises, the net average daily hotel rate (ADR) in Istanbul increased from 274 TRY in 2010 to 302 TRY in 2016 (STR 2016). The city has been experiencing a rapid and simultaneous development in room prices and demand within the last two decades; thus tourism demand in Istanbul might be considered inelastic. However, despite various negative side effects associated with tourism on local quality of life (e.g., congestion, inflation, increased crime rates, pollution, immigration, and social change) so far no specific tax on tourism activity in Istanbul has been introduced. On the contrary, the conventional sales tax on accommodation (which was reduced from $18 \%$ in 2008 ) is currently $8 \%$ in Turkey. Thus, Istanbul has been chosen as a good case study area for investigating attitudes towards the implementation of sustainability and a lodging tax. 


\section{Methodology}

This research attempts first to identify the areas that need investment for a better tourist experience and, secondly, to determine a level of tax tourists are willing to pay to fund those investments based on a demand side perspective. Because of the exploratory nature of the study a qualitative approach based on semi-structured in-depth interviews (see Appendix A) was used to identify perspectives of tourists concerning the introduction of a tourist tax in Istanbul. Since the tax issue is a sensitive matter involving various stakeholders, this technique is considered optimal for collecting valid data. Tourists were requested to answer a set of open-ended questions concerning the areas that need investment in the city, degree of tax that they are willing to pay, and their price sensitivity. Finally, they were also asked about their thoughts concerning lodging tax as a source of funding for measures to enhance the destination's sustainability.

After a series of open-ended questions were identified, an expert panel of two scholars and a pilot test on three tourists were also conducted. Based on the feedback some questions were either removed or refined. For example, one of the questions trying to measure the price elasticity, "How much would you pay for an upgrade if the current room you reserved was unavailable?", was perceived to be irrelevant by experts and, therefore, removed from the survey. Another question about the daily spending was described as confusing by the respondents during the pilot test and reworded to enquire about the total cost of travel rather than the daily spending. Thus, a higher content validity would be expected.

Interviews were conducted between 11 October and 27 November 2016 at major tourist attractions in Istanbul (e.g., Hagia Sophia, Topkapi Palace), as well as the two major international airports. A total of 22 tourists were interviewed although 44 were initially approached. Some respondents were eliminated because they had not yet spent a night in the city (1) or were business travelers (3) funded by their employers. The rest of the tourists (18) refused to participate in the study usually claiming that they did not have the time. Interviews lasted 27-59 min and each interview was electronically recorded and transcribed during the same day. After 22 interviews, the authors decided that data saturation had been reached and agreed that additional interviews would not provide any new findings.

Data collected were subsequently coded by each author in order to make a holistic sense of feedback received before grouping and interpreting the processed data (Mehmetoglu and Altinay 2006). At the end of the coding process, themes and thoughts were refined until a desirable level of abstraction was achieved to explain the uses and level of tourist taxation. After the coding process was over, authors discussed their interpretations; the content as well as field notes (non-verbal clues, gestures, approach) were analyzed again, compared with extant literature and secondary data, and agreed on findings discussed in the next section.

\section{Results}

The average age of respondents was 30. Most of them were male (13), and the mean annual net income per person was around 16,000 euros. A total of 18 different countries were represented in the sample, and these were mainly in Asia (9), Europe (7), and Africa (5). Participants were also usually travelling with their families (12) and friends (7), while only three were traveling alone. Although most were first-time visitors to Istanbul (13), there were also some repeat visitors to the city. Among others, study participants were asked to reveal their reservation lead time, and the median lead time was identified as eight weeks. Thus, evidently most respondents had made their reservations two months in advance. These descriptive statistics of the sample are observed on Table 1. 
Table 1. Descriptive profile of respondents; $(\mathrm{pP})=$ per person.

\begin{tabular}{|c|c|c|c|}
\hline \multicolumn{2}{|c|}{ Gender } & \multicolumn{2}{|c|}{ Travel Partner } \\
\hline Male & 13 & Family & 12 \\
\hline Female & 9 & Friends & 7 \\
\hline \multicolumn{2}{|c|}{ Age } & Alone & 3 \\
\hline $18-24$ & 7 & \multicolumn{2}{|c|}{ Visit Frequency } \\
\hline $25-34$ & 8 & 1st time & 13 \\
\hline $35-49$ & 6 & 2nd time & 3 \\
\hline $50+$ & 1 & $3 r d+$ time & 6 \\
\hline \multicolumn{2}{|c|}{ Annual Net Income pP in Euros } & \multicolumn{2}{|c|}{ Length of Stay } \\
\hline $0-14,999$ & 12 & $1-3$ days & 2 \\
\hline $15,000-29,999$ & 7 & 4-6 days & 7 \\
\hline $30,000+$ & 3 & $7+$ days & 13 \\
\hline \multicolumn{2}{|c|}{ Nationality } & \multicolumn{2}{|c|}{ Reservation Lead Time } \\
\hline Asia & 9 & $1-3$ weeks & 5 \\
\hline Europe & 7 & $4-6$ weeks & 3 \\
\hline Africa & 5 & 7-9 weeks & 9 \\
\hline North America & 1 & $10+$ weeks & 5 \\
\hline
\end{tabular}

\subsection{Areas that Need Investment}

One of the main objectives of the study was to explore tourists' thoughts about possible areas of spending for collected tourism-related tax money. Respondents were asked to consider if they had the decision-making authority where they would like to spend this tax money and how this could be used so that the value they received from their vacation might be improved. Participants were usually happy with the services provided in the destination. Yet the need for some additional improvements was also mentioned. A total of 41 items that relate to enhancement of tourist experience were identified based on the content analysis of transcriptions. These improvements were further grouped under general infrastructure, tourism superstructure, tourist services, and community welfare themes. This typology is displayed in Figure 1 and discussed below.

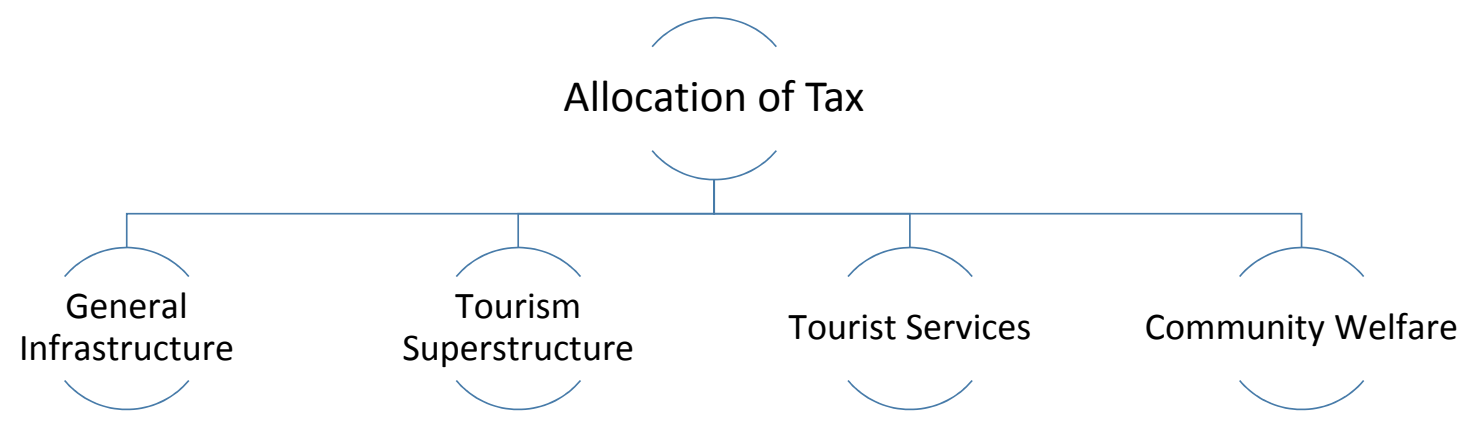

Figure 1. Typology of tourists' choices for spending of their taxes.

General infrastructure refers to items that include improvements in services that are both used by locals and tourists. This theme includes such items as public transportation, cleanliness, congestion, traffic, safety and security. Particularly, safety and security were frequently mentioned by respondents. This is not surprising considering that since 2015 Istanbul as a destination and Turkey in general have been faced with various terror attacks and violent political events, including an attempted coup. Confirming this, R3 mentioned: “ . . you can feel the tension and risk, there is police everywhere with machine guns." Traffic, roads, cleanliness, congestion, and the transportation network were also mentioned as possible areas where improvement could be made. For example, R10 stated: " ... we are here to enjoy and use our time in an efficient way, but because of traffic and long queues we lose too much time." 
Infrastructural improvements that target an improved tourist experience were classified under the tourism superstructure theme. In contrast to the general infrastructural issues that also target locals, tourists mentioned specific improvements in the tourism-related superstructure. Improvements in signage in foreign languages, the restoration and maintenance of tourist attractions and old buildings, improving airport capacity and customs services, extended closing times for touristic attractions, and so forth were grouped under this category. R22 elaborated on the issue as follows: " . . the signage should be improved for tourists; it is very hard to find your way in the city. [ ... ] ticketing services are too slow at museums and the closing times are too early. It took us two hours to buy the ticket to Hagia Sophia, and when we were inside we had less than an hour to visit the place. The visits are dull as well, there is no visual material or information available. The sites should also be better maintained. Some old houses are left to decay and this is bad."

Information provision services, additional recreational facilities (e.g., parks, theme parks), events and festivals, Wi-Fi services for tourists, quality improvements in accommodation services, and the availability of guide books were classified as tourist services. These items also relate to additional services for tourists that would improve their overall experience in the destination. In particular, tourists considered information provision services and Wi-Fi connection for foreigners as problematic. Comparing Istanbul with London, R2 mentioned: “ ... we have tourist service staff at touristic attractions and major transportation hubs, these people in red jackets help tourists and assist them. We also have information offices for tourists. [ ... ] even if you also have them here they are not visible." Talking about the Wi-Fi problem R5 stated: "I am paying 70 TL (20 euros) per day for the Wi-Fi service and you have to buy a local SIM card, which is not really convenient. It is important to use online maps, because the locals do not really speak English. There should be free wireless service for tourists particularly at some areas such as the airport and historic sites." Theme parks, events and festivals, cultural activities, zoos, seaside and countryside activities were also mentioned as potential services that would contribute to a better tourist experience.

Finally, some situational factors that relate to community welfare were also mentioned. Improvements in the foreign language skills of locals, better management of refugees and beggars, and helping the poor were coded under this theme. There has been a large inflow of refugees, particularly from Syria and Iraq, to Turkey within the past few years. Various reasons make these people leave refugee camps and live in large cities including Istanbul (Dincer et al. 2017). This situation has a major impact on tourists' image of the city. Most of these visitors believe refugees should be managed better, while some also confuse refugees with locals. For example, R4 mentioned: “ . . if I had a choice I would spend more to help people who are in difficult economic conditions. It is a humanitarian issue, but sometimes you cannot walk without being approached by one of these beggars. Sometimes it can get a bit intrusive and even aggressive ...." Various respondents also mentioned that the foreign language skills of hosts should be improved. R16 mentioned: “ . . people need to be taught at least one foreign language."

\subsection{Willingness to Pay Tourism Tax}

Respondents were also asked whether they would be willing to pay an additional tax if that meant an improvement in tourist experience and the amount of tax that they consider reasonable. Most respondents (18) mentioned that they would be willing to pay a tax for an improved tourist experience. For example, R6 mentioned that he can pay an additional 12 Euro per day for a free tourist Wi-Fi service.

Regarding the amount of reasonable tax per person $(\mathrm{pP})$, per day $(\mathrm{pD})$, the minimum rate suggested was 0.4 euros and the maximum tax was 21 euros, with 4.8 euros being the average. Hence tourists believe a reasonable tax should be around 5 euros $\mathrm{pP}, \mathrm{pD}$. It could also be observed that participants base their assumptions on prices and taxes in their own countries. For example, R17 stated: "Everything here is very inexpensive compared to home, for example, the hotel that we are staying in, if we had that hotel at home it would probably cost five times more, so even a $10 \%$ tax is a small 
amount ... ." European participants in general consider that a higher tax rate is quite reasonable compared to Asian respondents since for the latter VAT tends to be far lower. Experienced travelers were also more likely to pay more taxes. Corroborating these opinions R5 stated: "For European tourists, tax should not be a problem. In London you have to pay more, in France, they make you pay 1 euro per night besides the regular VAT. [ ... ] same in Rome, Sofia. Actually it's everywhere. [ ... ] if you go to Pakistan they will ask you 10 Euro Tax. [ ... ] people coming from Europe like Germany and Belgium [ ... ] are used to taxes ...."

Respondents also stressed that the tax rate would change based on a percentage rather than a fixed amount. For example, R7 mentioned: "If someone is staying in one- or two-star hotel and another is staying in five-star hotel you cannot ask the same tax from these two persons. It should be around $5-7 \%$ depending on the hotel price. If it (room rate) is 100 euro, then the tax should not be more than 5 euro."

In order to determine the extent to which respondents are sensitive to price increases, two separate questions using a cost plus approach were also utilized. The first question enquired about the total cost of travel (CostOriginal) and the second question dealt with how much increase in the $\operatorname{cost}(\Delta$ CostCeiling) would not change respondents' decision to travel to Istanbul. These values are displayed at Table 2. Hence each participants' indifference to price increases (e.g., tax increase) was measured using the following formula:

Price Sensitivity $=\Delta$ CostCeiling $/$ CostOriginal

Table 2. Respondents' willingness to pay (WTP).

\begin{tabular}{cccc}
\hline Respondent & CostOriginal & $\boldsymbol{\Delta C o s t C e i l i n g}$ & Indifference Ratio $\%$ \\
\hline R1 & 2000 & 1000 & 50 \\
R2 & 600 & 60 & 10 \\
R3 & 385 & 130 & 34 \\
R4 & 500 & 100 & 20 \\
R5 & 500 & 200 & 40 \\
R6 & 670 & 400 & 60 \\
R7 & 2050 & 205 & 10 \\
R8 & 2000 & 50 & 3 \\
R9 & 1535 & 1025 & 67 \\
R10 & 640 & 640 & 100 \\
R11 & 1750 & 235 & 13 \\
R12 & 300 & 30 & 10 \\
R13 & 4755 & 2850 & 60 \\
R14 & 3330 & 950 & 29 \\
R15 & 1165 & 50 & 4 \\
R16 & 1750 & 585 & 33 \\
R17 & 1710 & 515 & 30 \\
R18 & 380 & 50 & 13 \\
R19 & 950 & 475 & 50 \\
R20 & 430 & 50 & 12 \\
R21 & 95 & 50 & 53 \\
R22 & 255 & 255 & 100 \\
\hline
\end{tabular}

The price sensitivity of tourists might be utilized to obtain optimum prices. Because taxes in general increase the cost of a product or service, price sensitivity might also offer an idea about how tourists might react to a possible tax rate increase. The respondents' indifference to price increases was between $3 \%$ and $100 \%$. For example, R 8 who had a 2000 euro budget for his trip to Istanbul, stated he would not consider coming even if there was only a 50 euro increase in the cost of his total travel, whereas R10 and R22 demonstrated high indifference to price increases. They both indicated they would still come to Istanbul even if the total cost was double the current amount. The average ratio 
of indifference was calculated as $36 \%$. Thus, the majority of respondents might still come to Istanbul even if the total cost was increased by one third. A previous visit was also a factor affecting WTP. For example, R19 mentioned: "Honestly speaking, I won't (come again). Because we've visited Turkey four times and we can visit other countries." Another finding supporting the low price elasticity of respondents was value for money they received from their vacation in Istanbul. All participants believe that they received a good value for the price they paid in the city. For example, R18 stated that the prices in Turkey was very cheap and the trip was a very good value for money. Hence, it might be claimed that there is a consumer surplus considering tourists' spending in Istanbul.

WTP is widely adopted in tourism literature (e.g., Birdir et al. 2013) to measure tourists' tendency to pay for issues targeted towards enhancing sustainability. Respondents were also asked whether they would voluntarily pay an additional amount to be used to minimize the adverse effects of tourism activity on nature, locals, and public services. A rather mixed feedback was obtained from this question. Most of the participants (13) confirmed the willingness to volunteer a financial contribution for such matters, yet others (9) thought otherwise stating that these sustainability issues are responsibilities of local governments. Although some participants agreed on the fact that tourists create a burden, they stated it is not their obligation to correct these adverse effects. For example, R1 stressed: "Yes, tourists create a certain pressure on local resources and public services, but I think for tourists who decide to visit a city they are already paying that. They already spend more in the country, support local shops, restaurants, create jobs, etc. Yes, we use the metro but we pay for it, we do not ride for free ... so it is a little unfair to expect more. I just want to pay like everyone else, not something extra [...] The costs tourists create; I believe is less than what they generate. It is governments' responsibility to take care of the environment or whatever it is." On the other side most tourists were more likely to contribute voluntarily. For example R15 stated: "We'll pay a little bit extra if we knew it would be going to good cause."

Hence, although tourists are willing to pay for measures that would lead to improvements in their experience at the destination, they are more reluctant to pay for internalizing the external impacts of tourism. It should also be stated that tourists are more likely $(81 \%)$ to pay an additional amount of tax when earmarked with improvements in their experiences, but for a volunteer payment to be spent on measures relating to destination sustainability this rate falls to only 59\%. Understanding perceptions of travelers visiting the destination concerning WTP, tax rates, and their allocation is crucial to create an efficient and fair tax system. This would not only identify the optimum level of tourist taxes but also a just allocation of funds created from tourism.

\section{Discussion and Conclusions}

The main tourist product in Istanbul is its heritage, nature, local people, and culture (Ertugral and Dincer 2003). The relationship between the industry and the local people, therefore, should be more symbiotic and mutually supporting (Gursoy et al. 2002). Sustainability is also discussed as an important factor for destination competitiveness (Kozak and Martin 2012). Thus, there is an urgent need for policy makers, industry practitioners and other stakeholders to realize that a fund (which might be collected through local lodging taxes) is needed to ensure sustainability of this growth in demand for destinations like Istanbul, in order to avoid a point of no return that would also damage the tourist experience and the overall destination image.

This paper analyses how tourism can be taxed efficiently and in a just manner by local authorities, as well as investigating possible reactions to a hypothetical lodging tax for Istanbul, Turkey. Istanbul, just like many urban destinations in the world, has been experiencing increased pressure on local resources and public services stemming from increased tourism activity. Funds needed to compensate the sustainability of tourism development can be created through a tourist tax. Although a definitive conclusion could not be made using the findings, we believe valuable feedback was obtained to aid in the analysis of a tax decision and a background for future studies. 
While general taxes collected are sent to a central general fund, lodging taxes, defined as special taxes are expected to be spent on tourism related expenses by local government (Litvin et al. 2006). These special taxes are said to be earmarked, meaning their spending is restricted. This was confirmed by the findings of this study. Tourists are more willing to pay for investments that might improve their experiences. Yet according to Hiemstra and Ismail (1993), only 54\% of the lodging-specific taxes are being used directly or indirectly for tourism related expenditures in a destination. However, in developing countries such as Turkey, the local governments and municipalities lack the financial resources and empowerment to decide independently from central government (Göymen 2000) on how to spend tax money. This situation creates an additional inefficiency in spending the funds allocated by the central government (Tosun 2001).

Therefore, funds collected from tourism activity at a destination should be spent particularly on areas that enhance tourist experience (i.e., general infrastructure, tourism superstructure, tourist services and community welfare) in order to ensure long-term growth in tourist tax revenues. The tourist tax should also be used to benefit those taxed or negatively affected in order to ensure justice of taxation policies (Litvin et al. 2006). Confirming this, R7 mentioned: "If you are collecting tax from tourists, they should be spent for the tourist facilities and for the betterment of the tourists (experience). In that way your tourist growth will increase and your tourism industry will benefit. I don't find it right to impose taxes on travelers for an issue that the state should deal with. That is somewhat exploitation of tourists. As a tourist I already pay taxes and when I decide to come I already spend money, so it is not logical to pay for things I will not benefit from in long term [ . . ] I do not think I should pay for what is used more by local residents than tourists."

The sustainability of a destination is also regarded as an important criterion for the long-term success of a destination. Yet it costs money to maintain and preserve natural and cultural heritage, the quality of local life, and so forth (Mihalič 2000). After consulting with 54 scholars who published on sustainability, Miller (Miller 2001) found that no single group of stakeholders (among local residents, tourists, local government, industry and national government) should solely be responsible for the burden created by sustainability. However, it was stated by the respondents that governments (local and national) should primarily be accountable as the industry is not able to regulate itself and take the responsibility. Our findings also reflect that tourists are somewhat reluctant to take on the liability concerning sustainability issues and related costs. For example, R12 surmised: "We are already paying an important amount of tax and spending money in the destination. Solving the structural problems of general public should not be tourists' responsibility."

Tourists think they are creating economic benefits, which are improving local quality of life. According to them they should have better and more convenient access to public services and common resources such as safety/security, transportation, scenery, landscaping (Pizam 1978). When probed about the use of shared resources, R2 also stated: "I do not think there are any conflicts with local people, the services we use are also mostly available to locals at a larger scale. Besides tourism is very important for the economy of Turkey." It was also identified that when tourists are able to decide where the finances are to be spent, they would be more willing to pay a tax. Lopez-Sanchez and Pulido-Fernández (2016) also found that tourists have a higher WTP if they know why they are paying more. Tourists are naturally only one of numerous stakeholders at a destination. Although the travelers' perspectives and experiences should be considered, a commission involving local governments, tourism industry, and local NGOs to administer, collect and use the tax money is a more desirable and democratic way to manage taxes created by tourist spending. Considering the needs of the tourists besides those of the hosts would also lead to more sustainable development.

Therefore, policy makers should be cautious in introducing tax reform; sudden and major increases would both harm tourism tax receipts and those sectors that are highly dependent on tourism. Black markets and other bad practices are also likely to increase in volume as a means of avoiding the tax (Cetin et al. 2016). Being objective and realistic about a lodging tax is very important. There are debates especially about the spatial concentration of tourism in cities. A lodging tax can also 
be used: to direct and distribute tourism investment and demand; minimize the effects of seasonality by charging different tax rates during different periods; or encourage a longer average stay (2.8 nights for Istanbul) by applying a reduced tax for more nights. Given the facts stated above, research on the implementation of a lodging tax is still maturing and worthy of further study. This study constitutes a preliminary and exploratory work, before a series of planned studies on lodging tax, which will involve measurement of elasticity of demand and econometric models that would help simulate possible impacts of a lodging tax in Istanbul.

It should be stressed once again that this paper is a preliminary qualitative study offering a general framework for tourists' WTP for taxes and their perceptions about alternative uses of tax money. Although the study suggests a rate of reasonable tax and price sensitivity ratio, because of the limited sample recruited in a specific destination (i.e., Istanbul), the generalizability of the study and findings should be approached with caution. Therefore, offering a firm universal tax rate and suggesting relative importance of different uses of tax money is beyond the scope of this study. We leave this task for a planned second quantitative stage using the items suggested in this paper. However, the paper still provides various insights into WTP and areas of investment that would be considered when spending the tax money received from tourists. These results should be validated in a quantitative study conducted in various destinations with different characteristics (e.g., sun and beach resorts) and on a larger sample. Future quantitative studies might also look into personal (e.g., demographic) and situational (e.g., tripographic) factors that influence WTP. Another limitation in measuring WTP for sustainability is that there might be gaps between attitudes and behaviors of tourists. Particularly on sustainability issues, several authors (e.g., Juvan and Dolnicar 2014) found that tourists do not always walk the talk. Hence a more experiential approach concentrated on behaviors rather than attitudes might also provide better insights into the issue.

Acknowledgments: This research is funded by Scientific Research Project Office at Istanbul University. Project Code: 53540 .

Author Contributions: Gurel Cetin conceived and designed the theoretical framework of the paper and reviewed the literature; Zaid Alrawadieh collected the data; Gurel Cetin, Zaid Alrawadieh, Mithat Zeki Dincer, Fusun Istanbullu Dincer and Dimitri Ioannides participated in analyzing the data as well as writing the introduction and discussion sections.

Conflicts of Interest: The authors declare no conflict of interest.

\section{Appendix}

Interview Questions

1st Part

(age, gender, annual net income, nationality, size of group, party structure, length of stay, purpose of travel, type of accommodation, number of visits (if not first-time visitor), how long ago the trip was decided and reserved.)

2nd Part

1. You are paying a tax for your expenditures in the city. If you were the mayor of the city what would you do with the money raised from tourist tax?

2. How would the value you received from your vacation be improved? What areas need investment in order to improve tourist experience? What did you most dislike of Istanbul?

3. If an additional tax is needed to fix these would you be willing to pay for it? What do you consider a reasonable hotel tax per person per night (in $€$ )?

4. How much did this vacation cost you? Was it a good value for Money? How much increase in your total travel cost would not change your decision to travel?

5. You are paying a total of $8 \%$ VAT tax on your accommodation, would you still come to Turkey if the VAT rate was increased to $\% 18$. 
6. Is it fair for international travelers to pay a tourist tax? Do you believe tourists create a burden on local resources? Why and why not?

7. Would you be willing to pay additional amount voluntarily in order to minimize the costs of tourist activity on nature, locals and public services?"

\section{References}

Aguiló, Eugeni, Antoni Riera, and Jaume Rosselló. 2005. The Short-Term Price Effect of a Tourist Tax through a Dynamic Demand Model: The Case of the Balearic Islands. Tourism Management 26: 359-65.

Alvarez, Maria Dolores, and Şükrü Yarcan. 2010. Istanbul as a World City: A Cultural Perspective. International Journal of Culture, Tourism and Hospitality Research 4: 266-76. [CrossRef]

Ashworth, Gregory, and Stephen J. Page. 2011. Urban Tourism Research: Recent Progress and Current Paradoxes. Tourism Management 32: 1-15. [CrossRef]

BBC. 2017. The Country that Tourism Has Taken by Surprise. Available online: http://www.bbc.com/future/ story / 20170222-the-country-that-tourism-has-taken-by-surprise (accessed on 22 March 2017).

Birdir, Sevda, Özlem Ünal, Kemal Birdir, and Allan T. Williams. 2013. Willingness to Pay as an Economic Instrument for Coastal Tourism Management: Cases from Mersin, Turkey. Tourism Management 36: 279-83. [CrossRef]

Bonham, Carl, Edwin Fujii, Eric Im, and James Mak. 1992. The Impact of Hotel Room Tax: An Interrupted Time Series Approach. National Tax Journal 45: 433-42.

Burns, Peter M., and Andrew Holden. 1995. Tourism: A New Perspective. London: Prentice Hall.

Cárdenas-García, Pablo Juan, Marcelino Sánchez-Rivero, and Juan Ignacio Pulido-Fernández. 2015. Does Tourism Growth Influence Economic Development? Journal of Travel Research 54: 206-21.

Cetin, Gurel. 2014. Sustaining Tourism Development through City Tax: The Case of Istanbul. E-review of Tourism Research 11: 26-41.

Cetin, Gurel, and Anil Bilgihan. 2016. Components of Cultural Tourists' Experiences in Destinations. Current Issues in Tourism 19: 137-54. [CrossRef]

Cetin, Gurel, Merve Aydogan Cifci, Fusun Istanbullu Dincer, and Matthias Fuchs. 2016. Coping with reintermediation: The case of SMHEs. Information Technology \& Tourism 16: 375-92.

Choia, Chris Choi, and Ercan Sirakaya. 2006. Sustainability Indicators for Managing Community Tourism. Tourism Management 27: 1274-89. [CrossRef]

Chung, Jin Young, Gerard T. Kyle, James F. Petrick, and James D. Absher. 2011. Fairness of Prices, User Fee Policy and Willingness to Pay among Visitors to a National Forest. Tourism Management 32: 1038-46. [CrossRef]

Clarke, Harry, and Yew-Kwang Ng. 1993. Tourism, Economic Welfare and Efficient Pricing. Annals of Tourism Research 20: 613-32. [CrossRef]

Dincer, Fusun Istanbullu, Eyup Karayilan, and Merve Aydogan Cifci. 2017. Refugee Crisis after Arab Spring and its Impacts on Turkish Tourism: The Case of Istanbul. Journal of Tourismology 3: 1-17, in print.

Dodds, Rachel, Sonya Rita Graci, and Mark Holmes. 2010. Does the Tourist Care? A Comparison of Tourists in Koh Phi Phi, Thailand and Gili Trawangan, Indonesia. Journal of Sustainable Tourism 18: 207-22. [CrossRef]

Doxey, George Victor. 1975. A Causation Theory of Visitor-Resident Irritants: Methodology and Research Inferences. Paper presented at the Sixth Annual Conference of Impact of Tourism on Travel Research Association, San Diego, CA, USA, September 1975; pp. 195-98.

Dwyer, Larry, and Chulwon Kim. 2003. Destination Competitiveness: Determinants and Indicators. Current Issues in Tourism 6: 369-414. [CrossRef]

Ertugral, Suna Mugan, and Fusun Istanbullu Dincer. 2003. Economic Impact of Heritage Tourism Hotels in Istanbul. Journal of Tourism Studies 14: 23-34.

Fernández, Juan Ignacio Pulido, and Marcelıno Sánchez Rivero. 2009. Measuring Tourism Sustainability: Proposal for a Composite Index. Tourism Economics 15: 277-96.

Forgas-Coll, Santiago, Ramon Palau-Saumell, Javier Sanchez-Garcia, and Luís J. Callarisa-Fiol. 2012. Urban Destination Loyalty Drivers and Cross-National Moderator Effects: the Case of Barcelona. Tourism Management 33: 1309-20. [CrossRef]

Gago, Alberto, Xavier Labandeira, Fidel Picos, and Miguel Rodriguez. 2006. Taxing Tourism in Spain: Results and Recommendations. Working Paper No. 40; Milano: Fondazione Eni Enrico Mattei. 
Göymen, Korel. 2000. Tourism and Governance in Turkey. Annals of Tourism Research 27: 1025-48.

Green, Howard, Colin Hunter, and Bruno Moore. 1990. Assessing the Environmental Impact of Tourism Development: Use of the Delphi Technique. Tourism Management 11: 111-20. [CrossRef]

Gursoy, Dogan, Claudia Jurowski, and Muzaffer Uysal. 2002. Resident Attitudes: A Structural Modeling Approach. Annals of Tourism Research 29: 79-105. [CrossRef]

Hardin, Garrett. 1968. The Tragedy of the Commons. Science 162: 1243-48. [CrossRef] [PubMed]

Hassan, Salah S. 2000. Determinants of Market Competitiveness in an Environmentally Sustainable Tourism Industry. Journal of Travel Research 38: 239-45. [CrossRef]

Hicks, John Richard. 1946. Value and Capital, 2nd ed. Oxford: Clarendon Press.

Hiemstra, Stephen J., and Joseph A. Ismail. 1993. Incidence of the Impacts of Room Taxes on Lodging Industry. Journal of Travel Research 31: 22-26. [CrossRef]

Hinch, Thomas D. 1996. Urban Tourism: Perspectives on Sustainability. Journal of Sustainable Tourism 4: 96-110. [CrossRef]

Hughes, George. 1995. The Cultural Construction of Sustainable Tourism. Tourism Management 16: 49-59. [CrossRef]

Hunter, Colin. 1997. Sustainable Tourism as an Adaptive Paradigm. Annals of Tourism Research 24: 850-67. [CrossRef]

Istanbul Culture and Tourism Directorate. 2016. Istanbul Tourism Statistics. Available online: http://www. istanbulkulturturizm.gov.tr/Eklenti/49713, aralik-2016pdf.pdf?0 (accessed on 14 February 2017).

Juvan, Emil, and Sara Dolnicar. 2014. The Attitude-Behaviour Gap in Sustainable Tourism. Annals of Tourism Research 48: 76-95. [CrossRef]

Kozak, Metin, and Drew Martin. 2012. Tourism Life Cycle and Sustainability Analysis: Profit-Focused Strategies for Mature Destinations. Tourism Management 33: 188-94. [CrossRef]

Kozak, Metin, and Mike Rimmington. 1999. Measuring Tourist Destination Competitiveness: Conceptual Considerations and Empirical Findings. International Journal of Hospitality Management 18: 273-83. [CrossRef]

Litvin, Stephen W., John C. Crotts, Calvin Blackwell, and Alan K. Styles. 2006. Expenditures of Accommodations Tax Revenue: A South Carolina Study. Journal of Travel Research 45: 150-57. [CrossRef]

Lopez-Sanchez, Yaiza, and Juan Ignacio Pulido-Fernández. 2016. Factors Influencing the Willingness to Pay for Sustainable Tourism: A Case of Mass Tourism Destinations. International Journal of Sustainable Development $\mathcal{E}$ World Ecology 24: 1-14.

Mak, James, and Edward Nishimura. 1979. The Economics of Hotel Room Tax. Journal of Travel Research 17: 2-6. [CrossRef]

Mehmetoglu, Mehmet, and Levent Altinay. 2006. Examination of Grounded Theory Analysis with an Application to Hospitality Research. International Journal of Hospitality Management 25: 12-33. [CrossRef]

Mihalič, Tanja. 2000. Environmental Management of a Tourist Destination: A Factor of Tourism Competitiveness. Tourism Management 21: 65-78.

Miller, Graham. 2001. The Development of Indicators for Sustainable Tourism: Results of a Delphi Survey of Tourism Researchers. Tourism Management 22: 351-62. [CrossRef]

Miller, Graham, Kathryn Rathouse, Caroline Scarles, Kirsten Holmes, and John Tribe. 2010. Public Understanding of Sustainable Tourism. Annals of Tourism Research 37: 627-45. [CrossRef]

Miller, Dale, Bill Merrilees, and Alexandra Coghlan. 2015. Sustainable Urban Tourism: Understanding and Developing Visitor Pro-Environmental Behaviours. Journal of Sustainable Tourism 23: 26-46. [CrossRef]

Murphy, Peter E. 1985. Tourism: A Community Approach. London: Routledge.

Okumus, Fevzi, Umut Avci, Izzet Kilic, and Andrew Walls. 2012. Cultural Tourism in Turkey: A Missed Opportunity. Journal of Hospitality Marketing \& Management 21: 638-58.

Palmer, Teresa, and Antoni Riera. 2003. Tourism and Environmental Taxes. With Special Reference to the 'Balearic Ecotax'. Tourism Management 24: 665-74. [CrossRef]

Perez, Andrea, and Ignacio Rodríguez del Bosque. 2014. Sustainable Development and Stakeholder Relations Management: Exploring Sustainability Reporting in the Hospitality Industry from a SD-SRM Approach. International Journal of Hospitality Management 42: 174-87. [CrossRef]

Pizam, Abraham. 1978. Tourism's Impacts: The Social Costs to the Destination Community as Perceived by its Residents. Journal of Travel Research 16: 8-12. [CrossRef] 
Sariisik, Mehmet, Didar Sari, Selahattin Sari, and Muhsin Halis. 2011. Tourism Sector in Order to Recovering From the Recession: Comparison Analyses for Turkey. Procedia-Social and Behavioral Sciences 24: 181-87. [CrossRef]

Shareef, Riaz, and Michael McAleer. 2005. Modelling International Tourism Demand and Volatility in Small Island Tourism Economies. International Journal of Tourism Research 7: 313-33. [CrossRef]

Solow, Robert. 1974. Intergenerational Equity and Exhaustible Resources. Review of Economic Studies 41: $29-45$. [CrossRef]

Solow, Robert. 1991. The Eighteenth J. Seward Johnson Lecture. In Sustainability: An Economist's Perspective. Woods Hole: Woods Hole Oceanographic Institution.

Stapel, Jan. 1972. "Fair" or "Psychological" Pricing? Journal of Marketing Research 9: 109-10. [CrossRef]

Stavins, Robert N., Alexander F. Wagner, and Gernot Wagner. 2003. Interpreting Sustainability in Economic Terms: Dynamic Efficiency Plus Intergenerational Equity. Economics Letters 79: 339-43. [CrossRef]

STR. 2016. European Hotel Review: Istanbul. London: STR Global Share Center.

Su, Lujun, and Scott R. Swanson. 2017. The Effect of Destination Social Responsibility on Tourist Environmentally Responsible Behavior: Compared Analysis of First-Time and Repeat Tourists. Tourism Management 60: 308-21. [CrossRef]

Timur, Seldjan, and Donald Getz. 2009. Sustainable Tourism Development: How do Destination Stakeholders Perceive Sustainable Urban Tourism? Sustainable Development 17: 220-32. [CrossRef]

Tosun, Cevat. 2001. Challenges of Sustainable Tourism Development in the Developing World: The Case of Turkey. Tourism Management 22: 289-303. [CrossRef]

TurkStat. 2017. Tourism Statistics. Available online: www.tuik.gov.tr (accessed on 2 January 2017).

UNWTO. 2015. Tourism Highlights. Available online: www.unwto.org (accessed on 16 June 2015).

Valle, Patrícia Oom, Pedro Pintassilgo, António Matias, and Filipe André. 2012. Tourist Attitudes towards an Accommodation Tax Earmarked for Environmental Protection: A Survey in the Algarve. Tourism Management 33: 1408-16. [CrossRef]

Wilson, Suzanne, Daniel R. Fesenmaier, Julie Fesenmaier, and John C. Van Es. 2001. Factors for Success in Rural Tourism Development. Journal of Travel Research 40: 132-38. [CrossRef]

Young, George. 1973. Tourism: Blessing or Blight? Middlesex: Penguin Books.

(C) 2017 by the authors. Licensee MDPI, Basel, Switzerland. This article is an open access article distributed under the terms and conditions of the Creative Commons Attribution (CC BY) license (http:// creativecommons.org/licenses/by/4.0/). 